\title{
Introduction: Copying and Copyright, Publishing Practice and the Law
}

\author{
WILL SLAUTER
}

[N.B. This is the author's post-publication version of an article that appeared in Victorian Periodicals Review 51, no. 4 (Winter 2018), special issue on "Copyright Law and Publishing Practice in the NineteenthCentury Press." Please cite the final published version. DOI: 10.1353/vpr.2018.0044].

Nineteenth-century newspapers, magazines, and other periodicals thrived on copying, or so it seems. Specialists of the period have long noticed how contemporary editors reused and repurposed existing material, but recent changes in our own media landscape have prompted more sustained scholarly interest in how texts and images circulated in the information societies of the past. ${ }^{1}$ Meanwhile, the digitization of historical newspapers and periodicals — and the development of new tools for studying them — have enabled scholars to explore the phenomenon of reprinting on a new scale. Using computer algorithms that match substantially similar strings of text, scholars have begun to mine digital collections of newspapers in order to consider such questions as what kind of material was most often reprinted, what proportion of a given newspaper consisted of previously published material, and how the business and personal relationships among editors may have shaped the patterns found in the data. With respect to the circulation of illustrations, similar projects are underway. ${ }^{2}$

The freedom with which existing material was republished could be seen as a positive feature of the nineteenth-century periodical press, and some contemporaries celebrated it as such. Copying enabled news and commentary to spread; it helped editors to fill their columns, and it promoted the circulation of literature, visual culture, and practical knowledge. But there were different kinds and degrees of copying - from wholesale reprinting (with or without attribution) to abridgments and excerpts of various lengths - and what was acceptable in one context might 
be denounced as "theft" or "piracy" in another, regardless of whether the copying in question was actually prohibited by law. In addition, the interests of contributors and publishers were not always aligned. As long as her name was attached, a writer might welcome republication in other periodicals as a way of building a following among readers. The publisher who paid for the contribution might see things differently and decide to initiate a lawsuit or publicly shame copyists. In response, some editors self-consciously defended their "literary larceny" on political grounds as a means of making culture and knowledge available to a wider public. ${ }^{3}$ Others pointed out that it was hypocritical to complain about copying since all newspapers and periodicals relied on it to some extent. Ultimately, what was republished and by whom depended on a combination of factors, including the evolving conventions governing the writing and editing professions and the changing business strategies of publishers. But government policy also mattered. Political choices related to taxation (such as the stamp duty on newspapers), postal policy, telegraph regulations, and copyright law all shaped the wider political economy in which newspapers and periodicals operated. ${ }^{4}$

Of all the policy areas affecting newspapers and the periodical press, copyright has perhaps received the least attention from scholars. Most histories of nineteenth-century copyright focus on books, and most studies of Victorian newspapers and periodicals do not address the question of copyright in any detail. ${ }^{5}$ What role did copyright law play in the realm of newspaper and periodical publishing during the nineteenth century? Who sought out copyright protection, what were their motivations, and how successful were they? How did attitudes toward ownership evolve over time and vary by genre? Did contemporaries treat political news and reports of scientific discoveries the same as fiction, poetry, or illustrations? How did they deal with rivals who copied or imitated the title of their periodical? Finally, to what extent did the specific concerns of newspaper and periodical publishing shape wider debates about copyright law? 
These are some of the questions that motivated this special issue of Victorian Periodicals Review. With contributions by scholars in law, history, literature, and digital humanities, this collection of articles reflects an interdisciplinary approach to the history of copyright in which legislative and judicial developments are incorporated into a broader study of how newspaper and periodical publishing worked in various nineteenth-century contexts. In that sense, it builds upon research by scholars in law and the humanities - especially those inspired by the field known as book history - who have stressed the need to study legal developments in relation to the practices of authors, printers, and publishers. ${ }^{6}$ The contributors to this special issue do not assume that changes in the law automatically led to shifts in publishing practice or vice versa; instead, they treat copyright as one potential mechanism for regulating textual production and circulation, and not always the most important one. In some situations, copyright may have seemed irrelevant; in other situations it may have been desirable but contested; and in still others it may have been available but of doubtful utility or even counterproductive to the interests of authors and publishers.

In thinking about the relationship between the law and publishing practice, one initial obstacle is the chronology of copyright legislation and court decisions involving contributions to newspapers and periodicals. Unfortunately, establishing what kinds of works were protected by copyright at a given moment is not a simple matter of checking the statutes to see which categories of works were mentioned there. The statutes were subject to judicial interpretation, and it was only when a case was brought before a judge that the validity of a copyright claim could be determined. The first British copyright law, the 1710 Statute of Anne, referred to "books and other writings" in the preamble, but all of its provisions were for books. During the eighteenth century, some publishers of journals, magazines, and newspapers entered the titles of their serials under the Statute of Anne, but as far as I know their claims were never tested in the courts. ${ }^{7}$ In 
other areas, such as music publishing, legal action did lead courts to confirm that even works printed on a single sheet, such as musical scores, were protected by copyright. ${ }^{8}$ The earliest reported copyright decision I have found involving one periodical copying articles from another periodical is Wyatt v. Barnard (1814). A brief examination of this case will serve to introduce some of the aspects of periodical publishing that raised questions for copyright law, questions which would continue to be the subject of debate and litigation for much of the nineteenth century. Wyatt v. Barnard also shows how courts sometimes upheld copyright protection for works (such as contributions to periodicals) before these were mentioned in the statutes.

The plaintiff in the case, John Wyatt, was the proprietor of the Repertory of Arts, Manufacture, and Agriculture, a monthly publication that chronicled recent inventions for which patents had been issued, both in the United Kingdom and abroad. He sued John Barnard, publisher of the Tradesman, or Commercial Magazine, for copying articles that Wyatt had paid to be translated from foreign periodicals, as well as patent specifications that Wyatt had arranged to be copied from the originals held by the government. In his bill of complaint, Wyatt argued that his publication was of "great public utility," that it was the result of much "labour, trouble and expense," and that he was entitled to the "sole copyright thereof." According to Wyatt, this copyright prohibited others from reproducing any parts or extracts from his periodical. He sued Barnard in the Court of Chancery for an injunction restraining further publication of the translated articles and patent specifications that first appeared in the Repertory of Arts. He also demanded a share of Barnard's profits from the numbers of the Tradesman containing the "piracies."10

Barnard argued that none of the articles at issue in the case belonged exclusively to Wyatt. According to Barnard, the patent specifications were "public property" because anyone could consult them and make copies of them. ${ }^{11}$ The remaining articles had originated in other 
periodicals (in this case foreign ones), and Barnard claimed that there was a custom of the trade whereby editors knew that they could republish articles after they had appeared in other periodicals. As he put it in court filings, "it is the usual practice in publishing Magazines and Monthly Publications to take from each other such articles as are translated from Foreign Languages or are become Public Property from having appeared in other works." ${ }^{12}$ Barnard contested the idea that his copying harmed Wyatt's profits, especially since the articles usually appeared in his periodical a month after they had appeared in Wyatt's. Finally, Barnard argued that Wyatt had not done the translations himself but had paid someone to do them; therefore, he could not be considered the author for the purposes of copyright law. According to Barnard, Wyatt's publication was a compilation of existing materials rather than an original work of authorship. ${ }^{13}$

The dispute between Wyatt and Barnard brought to the surface some of the features of periodicals that created challenges for those who sought to protect them using copyright law. First, periodicals were collective works, and publishers like Wyatt sought rights over contributions made by others. Did payment to an author (or in this case, a translator) enable the publisher to claim copyright in the contribution? Second, most periodicals were miscellanies that contained both original and republished material. Could a publisher claim copyright in material that had already been published abroad or in the United Kingdom? In the case of public documents, did the labor and expense of selecting, copying, and preparing them for the press warrant protection against unfair use by competing publications? A third question was hinted at in Barnard's insistence that copying after a delay of one month could not harm the sale of the initial publication. Did lengthy copyright terms make sense for periodicals? In the case of books, sales might continue for years or even decades after publication, but could the same be said of 
periodicals? Should the interval of publication — daily, weekly, or monthly — be a factor in deciding what could be copied and when?

In Wyatt v. Barnard, the court refused to grant an injunction with respect to the patent specifications on the grounds that simply doing the work of copying them did not entitle Wyatt to restrain others from making their own copies. ${ }^{14}$ But Lord Chancellor Eldon, who decided the case, rejected the idea that all material appearing in periodicals should be open to copying. The existence of a custom, however widespread, did not excuse the need to obtain permission before reproducing a work protected by copyright. As Eldon put it, "The Custom among Booksellers could not control the Law." ${ }^{\prime 15}$ As to whether payment to an author or translator gave the publisher standing to sue, the court also ruled in Wyatt's favor. There was no international copyright agreement at this time, so a British publisher did not need permission from a French or German author to prepare a translation and publish it in the United Kingdom. But under British law, the resulting translation into English was considered an original work protected by copyright. Wyatt produced an affidavit showing that he had paid the translator to do the work. Wyatt also covered the cost of importing the foreign works that were translated. On these grounds, the court issued an injunction restraining Barnard from further publication of the translated articles. The case thus suggested that some writings in periodicals could be protected by copyright and that a publisher could acquire copyright from a contributor in exchange for pay. ${ }^{16}$

One question that Wyatt v. Barnard did not consider but would come up in later cases involving newspapers and periodicals concerned registration at Stationers' Hall. In the United Kingdom, registration of a title at Stationers' Hall was required in order to enjoy the statutory remedies for infringement, but failure to register did not forfeit the copyright. This principle developed in the courts during the eighteenth century and was codified by the Copyright Act of 1814. ${ }^{17}$ Since statutory copyright began with publication rather than registration, the realm of 
works protected by copyright was much larger than the list of registered titles would lead us to believe. (It should also be remembered that just because a title was registered did not mean that it was eligible for copyright or that the person making the registration was the rightful owner. These points could only be determined if and when a case came before a judge.) When the copyright law was revised again in 1842 , the new statute reiterated that copyright could not be lost as a result of a failure to register. It also made clear, however, that the title had to be registered at some point before any legal action for infringement could be brought. ${ }^{18}$

Interestingly, both the Copyright Act of 1814 and the Literary Copyright Act of 1842 contained special provisions for magazines, reviews, and "periodical publications": it was sufficient to register the first number in order to enjoy the benefits of the statute for all subsequent numbers. ${ }^{19}$ Newspapers were not mentioned in either the 1814 act or the 1842 act; the question of whether they could qualify for copyright as "books" or "periodical works" was only settled by the courts in the $1880 \mathrm{~s} .{ }^{20}$ But the fact that special provisions for the registration of magazines, reviews, and other periodicals were included in the statute as early as 1814 suggests that at least some publishers complained about the burdens that would result from having to register (and pay the fee) for each number of a periodical as if it were a separate book. ${ }^{21}$ Wyatt was clearly not the only publisher of periodicals interested in copyright.

As with many judicial decisions, however, it is difficult to say what effect Wyatt $v$. Barnard had on the practices of contemporary writers, editors, and publishers. The decision certainly did not put an end to debate about what kinds of contributions to periodicals and newspapers were protected by copyright, let alone how best to allocate rights between contributors and publishers. And trade customs may have been an important means of regulating copying despite the opinion of Lord Chancellor Eldon in Wyatt v. Barnard. Of course, the judgment in a dispute between two publishers did not preclude others from developing shared 
customs about what kinds of material could be copied and on what terms. But if a copyright suit was brought and a judge determined that the work was protected by copyright and the plaintiff was the rightful owner (either as the author or his assignee), then custom of the trade was not an adequate defense. On this point Eldon's opinion in Wyatt v. Barnard was affirmed in subsequent cases involving both magazines and newspapers. ${ }^{22}$ Nevertheless, the fact that defenses based on custom of the trade were still being raised near the end of the nineteenth century suggests the extent to which copyright law was uncertain and open to debate among editors and publishers.

In some contexts, informal norms and customs can be shown to have mattered more than copyright statutes or how judges interpreted them. In this special issue, the article by Aileen Fyfe, Julie McDougall-Waters, and Noah Moxham on the publishing practices of the Royal Society is a good example. The Royal Society was not a for-profit publisher, and its governing council recognized that attempting to enforce a monopoly on reports of its meetings went against the goals of disseminating knowledge and promoting the Royal Society's reputation. But the governing council did seek to control the terms by which the Royal Society's reports were usedparticularly the timing of publication in relation to the organization's own periodicals — and it always insisted that full credit be given to the Royal Society. Fyfe, McDougall-Waters, and Moxham reveal how the Royal Society adapted to the changing needs of its own members and the growth of commercial scientific journals by developing customary rules that they were able to enforce without recourse to copyright litigation.

Computational analysis provides another means of understanding the prevailing practices related to the reuse of existing publications. Focusing on the Edinburgh-based Caledonian Mercury for the period 1820-40, M. H. Beals, in her contribution to the special issue, seeks to better understand how much of the newspaper's content could also be found in other contemporary papers, and to identify some of the key attributes of this duplicated material, such 
as word-length, type of content, and whether the source was attributed. Beals stresses the need to combine computer-assisted matching of texts within the larger digital corpus (in this case Gale's British Library Newspapers) with a manually selected sample of a single newspaper (the Caledonian Mercury) in order to corroborate findings and test the limits of each approach. She documents how in this case "distant reading" through computational methods identified a much lower proportion of copied material than a "close reading" of the sample issues did. Crucial to Beals's analysis is attention to the different ways that editors acknowledged copied material, whether by naming the city of origin or crediting a specific publication, and how these patterns varied according to the length and type of article (news, commentary, numerical information, and so on).

Toward the end of the period studied by Beals, some newspaper publishers began to take an interest in copyright. As my own article suggests, this development depended upon changes in the structure of the news market, especially shifts in government regulation that altered the dynamic between London newspapers and the so-called provincial press. The reduction of the stamp duty in 1836 and its subsequent repeal in 1855 led a handful of London publishers to lobby for a special copyright in news reports that would be of much shorter duration (twelve or twentyfour hours) but which would protect the underlying factual details of news reports as well as their literary expression. These efforts, and subsequent initiatives by the Times in the 1890 s, led to debates about whether news reports were eligible for copyright at all and what the consequences of providing legal protection for "news and information" might be. These debates revealed how the time-sensitive nature of newspaper publishing made existing copyright remedies seem ineffective but also how the development of political arguments about the need for information to circulate successfully blocked efforts to create special copyright provisions for news. Still, a series of lawsuits brought by the Times at the end of the century clarified that the expression of 
newspaper articles - including reports of speeches taken down by reporters — could be protected by copyright, a change that enabled the Times and other publishers to syndicate their material.

The extent to which the law and practice of copyright varied by genre and form of publication is an important theme of this special issue. As Elena Cooper explains, section 18 of the Literary Copyright Act of 1842, which dealt with magazines, reviews, and "periodical works," also applied to encyclopedias. Encyclopedias were similar to periodicals in the sense that they were collective works whose publishers sought to control the rights over the individual contributions they paid for. Yet expectations about the shorter commercial life-span of periodicals and the interest of authors in being able to reissue their contributions in book form led to special rules that applied to periodicals but not to encyclopedias. Section 18 of the 1842 act represented an early legislative attempt to deal with the question of how to allocate rights between authors and publishers. Cooper explains how section 18 was the subject of criticism and numerous attempts at revision in the late nineteenth and early twentieth centuries. One important issue was whether an author who was paid for a contribution had the right to control subsequent publication of the article. Section 18 prohibited publishers of reviews, magazines, and other periodical works from reissuing a contribution separately without the permission of the author, but not everyone agreed on what constituted a separate publication. Some authors sued publishers who reused their contributions in supplements or Christmas numbers, and courts held that these should be considered separate publications in violation of the author's rights under section $18 .^{23}$ A recent study has pointed to such decisions as evidence of a legal climate that was relatively favorable to authors who contributed to collective works, especially when compared to the situation faced by freelance writers in the twenty-first century. ${ }^{24}$ But the history of copyright cannot be limited to the history of legislation and case law. There is clearly more room for case studies of individual authors and publishers that explore the contractual terms they developed and 
consider the extent to which the case law should (or should not) be seen as representative of wider cultural practices.

George Newnes's Tit-Bits, the subject of Thomas Vranken's article, was a publication that tested the limits of extracting as a mode of cultural production and a business model in its own right. Tit-Bits relied on copying, but it also became a brand that Newnes sought to protect against imitators in Britain and Australia. Newnes initially championed the careful selection of existing material and defended his practices against those who might object, for example, to the idea that a prize for the best contribution could go to a reader who had clipped a story from an existing publication. Newnes also faced criticism in the press, not least in the satirical magazine Punch. Although Newnes seems to have initially enjoyed testing the limits of cultural acceptability, within a few years he shifted strategies and began to highlight Tit-Bits's original contributions. Vranken suggests that this shift was motivated by a combination of factors, including Newnes's improved financial situation, which enabled him to pay some contributors, and his desire to attain respectability in the publishing world and in society at large. Unfortunately, not all readers of TitBits internalized this shift. When one of them submitted a previously published story and Tit-Bits printed it, Newnes found himself the defendant in a lawsuit brought by the original author. ${ }^{25}$

Newnes was not alone in trying to enjoy exclusive use of the title of his publication. But was it possible to protect the title of a newspaper or periodical using copyright or trademark law? As Lionel Bently's article shows, this question was addressed in a number of court cases and legal commentaries and was of great interest to publishers operating in a competitive marketplace where imitations were common. The same question arose in the field of book publishing, but the stakes for serials such as newspapers and magazines were different because of the need to use a stable and distinctive title to attract subscribers and advertisers. Publishers understandably sought to stop rivals from using an identical or substantially similar title to usurp their customers, but 
this goal tested the limits of copyright law. Not only were most titles seen to lack sufficient "originality" to qualify for copyright, but as Bently notes, copyright law prohibited others from reprinting the same work, whereas disputes over titles often involved the accusation that the defendant was presenting a different work as if it were the same as (or a continuation of) an existing serial. Many publishers and some legal commentators referred to "copyright in titles" even after courts denied copyright protection for them. Over time, as Bently explains, publishers learned how to exploit the emerging law of trademarks, but their actions also led courts to develop rules that restricted injunctions to certain situations. Among other factors described by Bently, courts considered whether the defendant's use of an existing title was likely to deceive ordinary purchasers, who were assumed to be fairly adept at distinguishing one publication from another. By reconstructing the different understandings of the law expressed by lawyers and judges on the one hand and publishers on the other, Bently provides a model for studying the evolution of legal thinking and practice in the midst of widespread uncertainty about the acquisition and scope of different kinds of rights.

Many of the legal questions explored in this special issue remain relevant today, not least for scholars working with digital collections protected through a combination of copyright, database rights, and contract law. Paul Fyfe's article explores these issues, comparing the situations in the United States and the United Kingdom. He shows that the legal concerns faced by libraries and researchers extend far beyond the question of which works have fallen into the public domain. As it turns out, even answering that question is difficult because of the complex rules for collective works under the 1842 and 1911 statutes in the United Kingdom, the difficulty of identifying current copyright owners, and the desire of libraries to avoid conflict with commercial database developers (with whom they are often in partnership). After explaining how the British Library and the National Library of Wales have dealt with such problems, Fyfe 
considers how the law affects what researchers are able to do with digital collections of historical newspapers. In particular, he discusses the statutory exceptions for text and data mining (TDM) in the United Kingdom and the provisions for "fair use" (in the United States) and "fair dealing" (in the United Kingdom). Situating recent trends in newspaper and periodicals research in the evolving legal landscape, Fyfe suggests some of the limits and future possibilities of employing "fair use" and other exceptions to copyright law to unlock the scholarly potential of digital collections.

I would also like to end this introduction with a discussion of limits and future possibilities. This special issue contains some gaps that should be pointed out here and others that the readers of $V P R$ will no doubt notice. Some of these can be explained by the decision to identify contributors through a call for papers (issued in 2015) and then to invite these contributors to a workshop (2017) in which draft articles were discussed and developed. ${ }^{26}$ Proceeding with a call for papers, rather than soliciting specialists to contribute on assigned topics, had the advantage of identifying some of the scholars interested in this field and encouraging them to develop their own research, but it also meant that certain areas would not be adequately covered. Regrettably, there were no proposals that focused on illustrations, despite the fact that the growing presence of images in print raised important questions for copyright law. ${ }^{27}$ There were also no submissions focusing on fiction. Although the development of syndication has received some attention, the ways individual authors dealt with questions of copyright deserves further study. ${ }^{28}$ Poetry is also absent here, despite the importance of newspapers and periodicals as venues for poetry. ${ }^{29}$ The international and colonial dimensions of copyright are also under-represented. Although the cultural and legal history of international copyright has been studied, most of the research has focused on books, and the rules worked out for newspapers and periodicals were different. ${ }^{30}$ Music appearing in periodicals also should not be neglected in 
future research. These and other gaps suggest that this special issue should be considered an opening volley in a relatively new field, leaving room for subsequent scholarship in the form of articles, monographs, and edited volumes. We hope to encourage further work into how copyright was understood (and misunderstood) in the past; how it was embraced, rejected, or ignored; and how the practices of writers, editors, and readers were shaped by changing conceptions of what could be copied and how the work of others should be acknowledged.

Université Paris Diderot - Institut universitaire de France

\section{NOTES}

${ }^{1}$ Examples include Darnton, "Early Information Society"; Feely, "Scissors and Paste"; Slauter, "Paragraph as Information Technology"; Nicholson, "You Kick the Bucket"; and Pigeon, "Steal it, Change it, Print it."

${ }^{2}$ See, for example, Cordell and Smith, Viral Texts, and M. H. Beals's contribution to this special issue. Paul Fyfe, Thomas Smits, and others are currently working on techniques for identifying and classifying republished illustrations.

${ }^{3}$ For a case study in how the poet Frances Browne navigated questions of newspaper reprinting see Easley, "Nineteenth Century." For an example of editors defending unauthorized republication on political grounds, see Feely, "What Say You."

${ }^{4}$ See John and Silberstein-Loeb, Making News, and Law, "Distribution."

${ }^{5}$ Recent studies of copyright beyond the book include Cooper, Art and Modern Copyright, and Slauter, Who Owns the News?. The question of copyright for periodicals in nineteenth-century America is discussed in Slauter, "Toward a History," and Haveman and Kluttz, "Cultural Spillovers.”

${ }^{6}$ See Johns, Piracy; McGill, "Copyright and Intellectual Property”; and Alexander and GómezArostegui, Research Handbook on the History of Copyright Law. 
${ }^{7}$ Slauter, Who Owns the News?, chapter 2. There were some suits brought by book publishers against magazines that abridged books without permission. See Deazley, "Statute of Anne." ${ }^{8}$ See Deazley, “Commentary on Bach v. Longman (1777)," and references therein.

${ }^{9}$ Bill of Complaint of John Wyatt, June 29, 1814, Wyatt v. Barnard (case W1814 W34), C13/174/19, National Archives, Kew.

${ }^{10}$ Ibid.

${ }^{11}$ Answer of John George Barnard, December 22, 1814, Wyatt v. Barnard (case W1814 W34), C13/174/19, National Archives, Kew.

${ }^{12}$ Ibid.

${ }^{13}$ Ibid.

${ }^{14}$ But note that a different decision was reached in Newton v. Cowie and Another (1827), 130 Eng. Rep. 759. In that case, the court held that creating an engraving based on a drawing of a patent specification required sufficient talent and labor to justify a copyright in the engraving even though the original drawings were available to the public. However, the court also held that the copyright on the engraving could not be used to stop others from employing their own labor and talent to create a new engraving of the same drawing.

${ }^{15}$ Wyatt v. Barnard (1814), 35 Eng. Rep. 408.

${ }^{16}$ Note that the question of whether copyright was owned by the person paying was dealt with differently by the courts in other situations, such as the relations between "employer" theater managers and "employee" dramatists. See Cooper, "Joint Authorship."

17 “Copyright Act, London (1814)," s. 5.

18 “Copyright Act, London (1842)," s. 24; Alexander, Copyright Law, 93.

19 “Copyright Act, London (1814)," s. 5; and “Copyright Act, London (1842)," s. 19. 
${ }^{20}$ A conclusive ruling was reached in Walter v. Howe (1881), discussed in my contribution to this special issue. See also Bently, "Copyright and the Victorian Internet," 89-101.

${ }^{21}$ Note, however, that the registration requirement in the 1814 act was bound up with the vexed question of library deposit. The statutory penalties for failure to register new works in section 5 of the 1814 act seem to have been designed to encourage registration so that the designated deposit libraries could identify newly published works for which they wanted to request free copies from the publishers. For more on the deposit controversy, see Alexander, Copyright Law, $47-62$.

${ }^{22}$ Maxwell v. Somerton [1874], 22 W.R. 313; Walter v. Steinkopff [1892], 3 Ch. 489. The latter case is discussed in my own contribution to this special issue as well as that of Thomas Vranken. ${ }^{23}$ Mayhew v. Maxwell (1860), 70 Eng. Rep. 766; Smith v. Johnson (1863), 66 Eng. Rep. 859. 24 D’Agostino, Copyright, 55-86. 25 Johnson v. Newnes [1894], 71 L.T. 230.

${ }^{26}$ I want to thank Patrick Leary for suggesting that I bring this CFP to the attention of the Research Society for Victorian Periodicals and Alexis Easley, editor of Victorian Periodicals Review, for encouraging this project from the beginning. On behalf of the authors, I would like to express my gratitude to Lionel Bently, Laurel Brake, and Jim Mussell for their extensive comments at the 2017 workshop held at Université Paris Diderot. Thanks also to Pierre-Carl Langlais, Stéphanie Prévost, Cécile Roudeau, Julien Schuh, and Sara Thornton for their remarks. The workshop was made possible by funding from the Institut universitaire de France and was hosted by LARCA (Laboratoire de recherches sur les cultures Anglophones, UMR 8225, Université Paris Diderot). 
${ }^{27}$ On the publication of photographs in the late nineteenth-century press, see Cooper, Art and Modern Copyright, chapter 3. Thomas Smits is currently researching the international circulation of images in illustrated newspapers.

${ }^{28}$ See Law, Serializing Fiction; Leary and Nash, "Authorship"; and Peterson, "Writing for Periodicals."

${ }^{29}$ See Hobbs, "Five Million Poems," and Easley, "Nineteenth Century."

${ }^{30}$ See, for example, Seville, Internationalisation of Copyright Law. For additional information on American reprints of British periodicals, see Barnes, Authors, 30-48.

\section{BIBLIOGRAPHY}

Alexander, Isabella. Copyright Law and the Public Interest in the Nineteenth Century. Oxford: Hart Publishing, 2010.

Alexander, Isabella, and H. Tomás Gómez-Arostegui, eds. Research Handbook on the History of Copyright Law. Cheltenham: Edward Elgar, 2016.

Barnes, James J. Authors, Publishers and Politicians: The Quest for an Anglo-American Copyright Agreement, 1815-1854. Columbus: Ohio State University Press, 1974.

Bently, Lionel. "Copyright and the Victorian Internet: Telegraphic Property Laws in Colonial Australia." Loyola of Los Angeles Law Review 38 (Fall 2004): 71-176.

Cooper, Elena. Art and Modern Copyright: The Contested Image. Cambridge: Cambridge University Press, 2018.

—. "Joint Authorship in Comparative Perspective: Levy v. Rutley and Divergence between the UK and USA." Journal of the Copyright Society of the USA 62, no. 2 (2015): 245-76. “Copyright Act, London (1814).” In Primary Sources on Copyright (1450-1900), edited by Lionel Bently and Martin Kretschmer. http://www.copyrighthistory.org. 
“Copyright Act, London (1842).” In Primary Sources on Copyright (1450-1900), edited by Lionel Bently and Martin Kretschmer. http://www.copyrighthistory.org.

Cordell, Ryan, and David Smith. Viral Texts: Mapping Networks of Reprinting in 19th-Century Newspapers and Magazines (2017). http://viraltexts.org.

D’Agostino, Giuseppina. Copyright, Contracts, Creators: New Media, New Rules. Cheltenham: Edward Elgar, 2010.

Darnton, Robert. "An Early Information Society: News and the Media in Eighteenth-Century Paris." American Historical Review 105, no. 1 (Feb. 2000): 1-35.

Deazley, Ronan. “Commentary on Bach v. Longman (1777). In Primary Sources on Copyright (1450-1900), edited by Lionel Bently and Martin Kretschmer. http://www.copyrighthistory.org.

—. "The Statute of Anne and the Great Abridgement Swindle." Houston Law Review 47, no. 4 (2010): 793-818.

Easley, Alexis. "The Nineteenth Century: Property Rights and 'Literary Larceny.'” In The Cambridge Handbook of Literary Authorship, edited by Ingo Berensmeyer, Gert Buelens, and Marysa Demoor. Cambridge: Cambridge University Press, forthcoming.

Feely, Catherine. "Scissors and Paste Journalism.” In Dictionary of Nineteenth-Century

Journalism in Great Britain and Ireland, edited by Laurel Brake and Marysa Demoor, 561. London and Ghent: The British Library and Academia Press, 2009.

—. "“What Say You to Free Trade in Literature?' The Thief and the Politics of Piracy in the 1830s." Journal of Victorian Culture 19, no. 4 (December 2014): 497-506.

Havemann, Heather A., and Daniel N. Kluttz. "Cultural Spillovers: Copyright, Conceptions of Authors, and Commercial Practices." Law and Society Review 52, no. 1 (2018): 7-40. 
Hobbs, Andrew. "Five Million Poems, or the Local Press as Poetry Publisher, 1800-1900." Victorian Periodicals Review 45, no. 4 (Winter 2012): 488-92.

John, Richard R., and Jonathan Silberstein-Loeb, eds. Making News: The Political Economy of Journalism in Britain and America from the Glorious Revolution to the Internet. Oxford: Oxford University Press, 2015.

Johns, Adrian. Piracy: The Intellectual Property Wars from Gutenberg to Gates. Chicago: University of Chicago Press, 2009.

Law, Graham. "Distribution.” In The Routledge Handbook to Nineteenth-Century British Periodicals and Newspapers, edited by Andrew King, Alexis Easley, and John Morton, 42-59. London: Routledge, 2016.

—. Serializing Fiction in the Victorian Press. Basingstoke: Palgrave, 2000.

Leary, Patrick, and Andrew Nash, “Authorship.” In The Cambridge History of the Book in Britain, vol. 6: 1830-1914, edited by David McKitterick, 172-213. Cambridge: Cambridge University Press, 2009.

McGill, Meredith L. "Copyright and Intellectual Property: The State of the Discipline.” Book History 16 (2013): 387-427.

Nicholson, Bob. “'You Kick the Bucket; We Do the Rest!': Jokes and the Culture of Reprinting in the Transatlantic Press." Journal of Victorian Culture 17, no. 3 (2012): 273-86.

Peterson, Linda H. "Writing for Periodicals.” In The Routledge Handbook to Nineteenth-Century British Periodicals and Newspapers, edited by Andrew King, Alexis Easley, and John Morton, 77-88. London: Routledge, 2016.

Pigeon, Stephan. "Steal it, Change it, Print it: Transatlantic Scissors-and-Paste Journalism in the Ladies'Treasury, 1857-1895.” Journal of Victorian Culture 22, no. 1 (2017): 24-39. 
Seville, Catherine. The Internationalisation of Copyright Law: Books, Buccaneers and the Black Flag in the Nineteenth Century. Cambridge: Cambridge University Press, 2006.

Slauter, Will. “The Paragraph as Information Technology: How News Traveled in the Eighteenth-Century Atlantic World." Annales. Histoire, Sciences Sociales: English Edition 67, no. 2 (June 2012): 253-78.

—. "Toward a History of Copyright for Periodical Writings: Examples from NineteenthCentury America." In From Text(s) to Book(s): Studies in Production and Editorial Processes, edited by Nathalie Collé, Monica Latham, and David Ten Eyck, 65-84. Nancy: PUN - Éditions universitaires de Lorraine, 2014.

-Who Owns the News?: A History of Copyright. Stanford: Stanford University Press, 2019. 